\title{
Reformed identity revisited: Proposals in the spirit of Ecclesia Semper Reformanda est
}

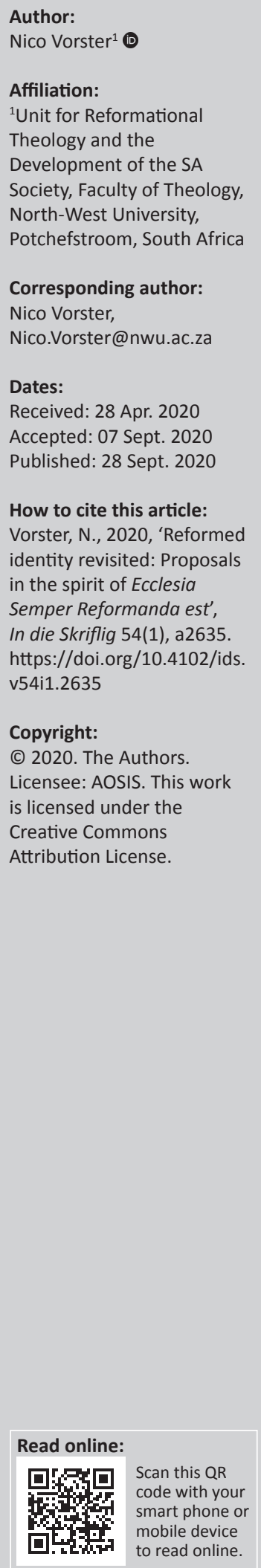

\section{Author:}

Affiliation:

${ }^{1}$ Unit for Reformation

Society, Faculty of Theology,

North-West University,

Corresponding author:

Nico Vorster

Dates:

Received: 28 Apr. 2020

Accepted: 07 Sept. 2020

How to cite this article:

Vorster, N., 2020, 'Reformed

in the spirit of Ecclesia

Semper Reformanda est',

Copyright:

C 2020. The Authors

Licensee: AOSIS. This work

is licensed under the
This article commences by reflecting on the evolving nature of traditions. In order to pass the continual test of plausibility and authenticity, traditions need to be flexible enough to incorporate new insights into its core intellectual matrix. Implausible elements need to be re-articulated or dispensed with. This rationale is subsequently applied to the reformed tradition who considers the necessity to continually reform itself (Ecclesia Semper Reformanda est) as a fundamental aspect of the tradition. Recently, various tenets of the reformed faith have come under scrutiny. These include the reformed faith's understanding of God's relation to creation; its view of human uniqueness; its understanding of original sin and the transmission of sin; and its supposed sola Scriptura approach to ethics. This article addresses these critiques by proposing that reformed theology incorporates the notion of creation as a gift in its thinking; that it dispenses with attempts to provide a historical narrative on the origin and transmission of sin and rather approach the theme from an existential perspective; and that it works towards an ethics that is scripturally based but ecclesiastically shaped.

Keywords: identity; creation; sin; Christ; justification; sanctification; church; virtue.

\section{Introduction}

Cultural traditions are social matrixes which contain worldviews about the meaning and purpose of life. They also include moral codes which define desirable and non-desirable outcomes, and guide adherents on how to relate to themselves and the outside world. To survive within rapidly changing environments, and to pass the continual societal test of plausibility and authenticity, cultural traditions have to evolve, but in a way that is commensurate with their core values. When core elements of a tradition are overthrown without caution or proper reason, a tradition may become unstable and implode. Hence, for a tradition to remain stable, it must align new knowledge to the fundamental intellectual matrix of the worldview. Outdated components have to be relinquished for the sake of plausibility and authenticity. If not, a tradition may become stagnant and outdated. The same is true of religious traditions.

The reformed Christian tradition is quite unique in that it incorporates the element of continual reform (Ecclesia Semper Reformanda est) as a key reference point in its self-understanding. Ecclesia Semper Reformanda est rests on two fundamental premises: First, it signifies a devotion to the teachings of the biblical canon as a key premise of the core intellectual matrix of the reformed tradition. Secondly, it holds that our noetic capacities are affected by sin and that our understanding of the teachings of Scripture are historically and culturally conditioned. Theological teachings therefore require continual reform.

Various leading theologians of the past century have been critical of the way reformed theology goes about with certain key themes in Christian theology. This article will focus on three specific critiques that are pertinent to the intellectual matrix of the reformed faith. Firstly, reformed creation theology is charged of emphasising the uniqueness of the human being to such a degree that it downplays the integrity and inherent value of the natural environment and makes environmental concerns subservient to human interests (see Conradie 2017). At the same time, the reformed emphasis on the absolute sovereignty and transcendence of God and its rejection of a realist ontology that views reality as participating in an analogical sense in God's being, is accused of playing into the secular view that the natural world is a mere instrument that be explained without any reference to God (Gregory 2012:37). Secondly, reformed doctrines of original sin and the transmission of sin is accused of being based on an implausible literalist understanding of the creation narratives and of a 'quasi-gnostic' biological 
understanding of the transmission of sin (see Ricoeur 1974:267, 276). Thirdly, reformed ethics is blamed for constructing an individualist ethics based on the principle of sola Scriptura which every person can decide for him- or herself based on Scripture what the Christian life entails. This supposedly leads to a disparate ethical system characterised by opposing truth claims (see Gregory 2012:92).

Some of the above-mentioned charges may be one-sided and inadequately nuanced, but they do identify possible weak spots in the reformed intellectual matrix that require reconsideration and elucidation. This article asks: How can the insights of leading scholars from the 20th and 21st century be utilised to enrich the reformed theological tradition with regard to these critiques? What new elements can be introduced to the reformed matrix and which components may require reconsideration?

In responding to these charges, I will engage with the views of several non-reformed scholars. The occasional use of these authors as interlocutors does not imply that I agree with their theologies as a whole, or that I intend to construct an eclectic theology of Christian identity. It does, however, affirm the reality that Christian identity is an evolving phenomenon and that a reformed Christian identity can be refined by listening to non-reformed voices and by learning from some of their perspectives while staying true to the fundamental tenets of a reformed logic.

\section{God, creation and human uniqueness}

Reformed ontology has always been marked by an effort to distinguish between the divine and created realms, yet to also relate them. Reformed theology maintains that God is sovereign and relates to reality through his Word and Spirit; not through a realistic presence in material reality. This has implications, especially for the reformed understanding of the relation between God and creation, the connection between the two natures of Christ, and the presence of Christ in the Holy Communion. Calvin maintained that God is sovereign and created all things ex nihilo. Reality finds its origin in God's creative word and acts and not in pre-existing matter. It revolves around God but is not part of his essence. He also held that the human and divine natures of Christ do not communicate their properties to each other, but only to the person of the Mediator and that Christ is present in the Holy Communion through his Spirit and not under the elements of bread and wine (see Calvin CO 1864-1900, 55.446; CO 2.348-349).

The question is whether reformed theology does not make too sharp a distinction between God and creation. Does the reformed faith not open itself to the charge of theism? Tillich (1952) famously defined theism as follows:

$\mathrm{He}[\mathrm{God}]$ is seen as a self which has a world, as an ego which is related to a thou, as a cause which is separated from its effect, as having a definite space and an endless time. He is a being, not being itself. As such he is bound to the subject-object structure of reality, he is an object for us as subjects. At the same time we are objects for him as a subject. (p. 184)

Luther argued that the gospels portrays God's relation to creation in three modes: In Christ, we see God acting as an object in correspondence with reality; in the resurrected Christ, we see God who appears and disappears in material reality without being confined to material limits, as omnipresent Being God acts as supernaturally present in all things without being limited by material space (Luther 1961:215-219). Tillich (1952:55) followed Luther in maintaining that God is not a being but Being itself, the Power of Being and the Ground of Being. Calvin, in contrast, resisted any conflation of divine and creaturely essences. He did recognise the cosmic working of the Spirit and the life-giving power of God's ruach in creation. But these themes appear sporadically in his thought, while the ontological distance between God and creaturely reality receives much emphasis.

Both the Lutheran and Calvinist positions have advantages and disadvantages. Luther's theology can be utilised to address ecological problems and affirm the inherent value of creaturely reality, but if we view God's being as incarnated in reality, it may lead to an undue deification of material properties. Calvin, on the other hand, maintains the qualitative difference between God and creature, but his stance may lead to a view of creation as a 'mere thing,' a temporary habitas for humans without any inherent or eternal value.

Gregory of Palamas's (1296-1359) distinction between the essence of God and his energies may serve as a possible bridge between Luther and Calvin. According to this view, created reality is not part of God's being, but the energies that flows from God's being radiates and transfuses God's power to the creaturely realm. The patristic fathers often used the image of the sun. The rays of the sun are not the sun itself, but they radiate the energy of the sun to the earth and invigorate growth. In the same manner, God's energies exert his power on created reality, without God being identified with created reality. It is furthermore suggested that the notion of creation as gift of God may serve as an intermediary position between Calvin's emphasis on the otherness of God and Luther's close connection of God to material reality. A gift is not identical with the giver's being or essence, but it signifies a very close relationship, because it is an expression of the character and disposition of the giver. A gift's value is always related to who the giver is and what the giver means to the receiver. The gifted nature of creation infers that the value of creatures cannot be abstracted from our relation to God or understood apart from God's continuous involvement in our live. Creation displays an aesthetic beauty that attracts and calls human beings to God. We discern and experience the sheer giftedness of reality in fellow creatures who inhabit the earth with us, natural resources that provide nourishment, mineral resources, our physical abilities to see, hear and 
move, and our rational capacities to act and shape. God's gifts, however, requires a creaturely response. A lack of response to God's blessings would evidently amount to an insult (see Milbank 1995:119, 121). We should therefore reflect on responding to God's gifts in an appropriate fashion. Our responses to God's gifts will inevitably be asymmetrical in nature. Creatures cannot possibly return the Creator's gifts in a commensurable manner. Our duty is therefore not to respond to God's gifts in a similar manner or to compensate God in an equal fashion, but to accept God's gifts with gratitude and to put them to use in a manner that serves God. At the same time, we have to accept that God does not owe us his gifts and that he can withdraw his blessings whenever it pleases him to do so (see Tanner 2018:57).

This bring us to the issue of human uniqueness. As stated earlier, reformed theology is critiqued for elevating the human above the animal realm and thus playing into ecological harmful discourses. The key to the debate is the theme of the imago Dei. Genesis 1:26-28 and various Pauline passages describe the human being as created in the image of God. Although the term image of God is not often used in Scripture, the force of the concept has exercised great influence in post-canonical Christian traditions. Interpretations of the concept have varied from grounding the image in the trinitarian structure of the soul (Augustine), in human characteristics such as rationality or consciousness (Irenaeus, Thomas Aquinas and Friedrich Schleiermacher), sociality and relationality (Barth and Zizioulas), and dominion (Luther, Melanchton and Von Rad). We cannot discuss these issues at length here, except to say that historical attempts to locate the imago Dei in a specific human feature have been highly problematic, because they tend to elevate certain human characteristics above other features that are equally part of our human make-up (see Gunton 2018:108). The Old Testament writers understood the human as an undivided psycho-somatic unity. The human being is a living being; he or she does not have a nepesh, but is nepesh (Wolff 2018:150; Gn 2:7). When God breaths his ruach into the human being, he or she does not 'acquire(s) a soul', but becomes 'a living being' (Jenson 2018:315). The Irenaeun notion of reason as the chief ontological characteristic of the human being and the Augustinian understanding of the image as residing in the soul has certainly encouraged the belief that 'we are more mind than we are bodies' (see Gunton 2018:108). Locations of the image in self-consciousness equally played into individualist understandings of personhood.

The biblical notion of the imago Dei is not essentialist in nature; it is not about human ontology or meta-physical ontology, but it concerns our calling as creatures of God. We are created to relate to God - fellow human beings and natural reality in a specific way and according to a specific pattern. Relating is characterised by a gift cycle which consists of receiving and giving (Gunton 2018:115). Ontological human capacities such as self-awareness, linguistics, moral agency and deliberation do not constitute the image in us; they are endowments of God that enable us to fulfil our commission and to stand in proper relation to God and fellow creatures. We receive these endowments in order to give to others. Our 'being in relation' is qualified in Genesis 1:26 as extending to inter-human and natural relations. We are created as 'male and female'. Again, we should be wary of construing this expression in essentialist terms. The intention in Genesis 1:26-28 is not to articulate the 'order of things' or to delineate the exact nature of the male and female relationship, but simply to state that relationality is an essential part of being fully human. Human interaction and the formation of bonds are made possible by the divine gift of sexuality, which allows humanity to multiply and to enter into social relationships. We have to respond to the gift of sociality by living in just and caring relationships with our neighbours, without whom our lives are incomplete. Unfortunately, the male-female differentiation in Genesis 1:26-28 has been used by classical theologians, most notably Aquinas, Luther and Calvin, to justify hierarchical gender conventions. This, however, contravenes the most basic message of the passage, namely that God alone, not gender or any other ontological characteristic, is the grounding source of human existence (see McClintock-Fulkerson 2006:105).

Genesis 1:26-28 and 2:15, secondly, identifies stewardship as an important part of our duty to give; we have to preserve, maintain and cultivate God's creation, but in a manner that reflects the glory of God's benevolent reign. The mandate cannot be interpreted as a right to exploit creation; this would amount to an act of rebellion against the creator God. We also do not have the right to determine what the telos of creation should be. This is a right that only the creator God can exercise. Our mandate, furthermore, does not imply that the human being can be abstracted or dislocated from nature as if the human is somehow a supra-natural being. In fact, Genesis 2 emphasises that human beings are created from the dust of the earth - they are embedded in nature. Gunton (2018:115) aptly remarks that 'we receive much of what we are from the world in which we are and from whose dust we come'.

Nevertheless, we cannot deny that the imago Dei affirms the uniqueness of the human being. The human person is the only creature who receives the commission to act as God's representative, and to respond directly to his moral commands. Tanner (2018:55) observes that 'unlike other inhabitants of the earth who are merely charged with furthering their own fecundity and prosperity, human beings reflect God by adopting God's own project of universal well-being'. Affirmations of human uniqueness is, in my view, too readily conceived as the source of human apathy about the environment. The fundamental origin of ecological degradation is wider in scope. It is caused by the gift of creation being abstracted and dislocated from the Giver. When the belief in human uniqueness is properly located within the perspective of gift and the duty to respond to the Giver, it is possible to address ecological 
degradation without resorting to the naturalist option of downgrading the human to the level of a mere biological organism.

\section{The transmission of sin}

The reformed doctrine on original sin was strongly influenced by Augustine's literalist understanding of the creation narratives which teaches that the original pair of human beings committed a sin that altered the moral and biological make-up of human nature as such. Augustine viewed the soul as the controller of the body of the human person. When the soul deserted God, it lost its control over the body so that the body fell prey to carnal desires and concupiscence. Reformed theology has attempted to explain the historical transmission of sin by using realist and federal explanations. The realist position follows Augustine in contending that original sin is biologically transmitted, because the whole of humanity was already included in Adam's sperm. The federal explanation claims that the sins of Adam are legally imputed to Adam's offspring, because Adam served as the representative of the whole human race in the original covenant of works that God set up with the original pair (see Van der Kooi \& Van den Brink 2017:320). Both positions create a variety of problems: Firstly, a literalist understanding of the creation narratives is neither reconcilable with clear scientific information on the natural history of humankind, nor with the intent of the creation narratives that operate within the world of wisdom, imagination, intuition and prophetic witness rather than historical proof (Barth 1955-1969:508). Secondly, both positions employ a concept of justice that separates human accountability from human agency. The human person is held accountable for the sins of other persons an original pair who supposedly either changed the biological make-up of human nature through their sinning (realist position) or sinned on the behalf of their posteriority (federalist position). Hence, the human person is considered as guilty for something he or she inherited either through procreation or through the imputation of guilt. Seen from this perspective, it becomes a matter of 'fate' rather than actual guilt (see Van der Kooi \& Van den Brink 2017:321). We need to ask: Are there not more plausible arguments at our disposal to explain the genuine insights of the doctrines of original sin and the total depravity of human beings?

Seren Kierkegaard (1813-1855) and Reinhold Niebuhr's (1892-1971) existential analysis of original sin shows, in my view, much promise. It can assist the reformed tradition in moving away from literalist errors, while staying true to the intellectual core of the reformed doctrine on sin. Kierkegaard ([1844] 2014) and Niebuhr (1945) posits that the human being is a synthesis between nature and spirit, necessity and possibility (Kierkegaard [1849] 1980:5). Our creaturely limitations create in us anxiety about dependence and vulnerability. On the one hand, we are material beings confined by space and time, physical needs and finiteness. Conversely, we are self-aware and conscious beings who have a sense of past, present and future, and are able reflect on things beyond the self. During the process of self-actualisation, we become acutely aware of the tensions between necessity and possibility, and the powers of death, meaninglessness and condemnation which threaten the core of our existence. Our decision-making processes are, as a result, characterised by intra-psychic and inter-personal conflicts. Intra-psychic conflicts are caused by the 'dizziness of freedom', that is, the infinite possibilities presented by the future (Kierkegaard [1844] 2014:23), while interpersonal conflicts emanate from the tension between exercises of freedom and the immediate interests of others. These conflicts create existential anxiety. According to Niebuhr (1945:195), anxiety in itself is not sin, because it is not an actuality; it can always be purged by faith. Yet, anxiety creates a psychological condition that creates a breeding ground for sin.

Sinning is not a necessity; yet, it is inevitable. We are not coerced or forced into sinning, but we predictably and foreseeably respond to insecurity by misusing our freedom to make ourselves 'doubly secure' (Niebuhr 1945:205). Instead of trusting God's providence, our anxieties and lack of trust in God lead to a life that is, according to Luther, curved inwards onto itself (see Van der Kooi \& Van den Brink 2017:299). Sin thus signifies a refusal to ground our existence in our relation to God; it denotes a lack of trust and faith in God's providence; a turning away from God's covenant; an attempt to take charge of our own destiny and to escape the limits of creaturehood. The estrangement is strikingly narrated in Genesis 3. The human being's first and almost immediate response to God's calling is to disobey God and 'to take sides against God' (Barth 2018:38). The disobedience then takes on a life of its own in a manner that humans cannot master or manage (see Westermann 2018:18). Our refusal of the life-giving power of God leads to death and emptiness (Gn 3 and 6). Paul takes up the basic themes in the creation narratives by emphasising the accountability of humans for their sins, the universal reach of sin, and spiritual death as its end result. He describes sinful identity as a life of disobedience ( $\operatorname{Rm} 5: 19$ ), a carnal mode of existence ( $R m$ 8:5) that does not sufficiently mirror the glory of God ( $R m$ 3:23).

Every person's life is characterised by a first moment when we betray God by misusing our freedom - a qualitative leap into guilt. 'Original sin' articulates the inevitability of sinning and the systemic, corporate and total power of sin. Human beings are tied and connected to one another not only in direct personal encounters, but also through bonds of kinship, social structures and historical chains of events. Social structures and group identities shape our lives profoundly and we may easily find ourselves 'in bondage to them' (Gorringe 2019:406). Tragically, structural sins are often only genuinely understood by those who fall victim to a system and experience its dark side. But even while experiencing the effects of these evils, they often struggle to respond without committing the same kind of atrocities. Postcolonial theology has called attention to the ways in which the socially 'oppressed' often reflect and mimic the 
ways of those who oppress to gain acceptance and privileges from the oppressor. This showcases how evil spirals can originate, flourish and entangle people within maladapted and distorted social structures.

Sin gathers momentum through distorted group identities. Distorted group identities originate where friendship and kinship are considered as more important than justice, and it often culminates in disturbing and potent social pathologies. Niebuhr (1945:201) perceptively remarks that the group is more arrogant, hypocritical, self-centred and ruthless in the pursuit of its ends than the individual'. Groups tend to generate a false sense of security, an illusionary feeling of power, a perverted sense of direction, and a suppressed sensitivity to personal accountability. Once sin becomes embedded in the social fabric and entrenched in systems or structures, it has succeeded in mutating from the realm of disparate 'acts' into a cohesive and destructive power.

Self-actualisation and identity formation require an appropriate model, an ideal pattern to be followed. Tragically, sin leads astray our understanding of right and wrong, and our ability to discern between ideal and distorted models. Calvin (1864-1900, CO 2.210) rightly emphasised the noetic effects of sin; it 'darkens' and 'blinds' our understanding. Identity formation is, as a result, a highly flawed and broken process. Distorted identity formations usually start by following a wrong model, leading to wrong patterns and habits being instilled in human lives. In other words, distorted identity formation has an infectious quality. Whole communities could embrace a distorted form of identity formation and the eventual outcome could be a full-blown social pathology.

\section{Reformed ethics and the Christian life}

The third contemporary critique levelled at reformed theology concerns its approach to ethics. I agree with Gregory (2012:92) that an ethics based purely on sola Scriptura where everyone decides for him- or herself what a Christian lifestyle entails, may indeed lead to 'a vast range of conflicting and irreconcilable truth claims'. Whether all strands within the reformed tradition indeed practises a Biblicist type of ethics, is open to debate. Different strands with reformed theology employ different kinds of methods. These methods usually range from literalist to contextual approaches.

Nevertheless, in what follows I will argue that ethics need to be ecclesiastically shaped. An ecclesial ethics is a communally defined ethics and hence can serves as a safeguard against a disparate free-for-all ethics. It rests on the premises that the church community constitutes the space wherein Christian character should be formed. The Christian life must be premised on the example of Christ as the Head of the church, and the unique character and calling of the church.
Reformed theology holds that God transforms human identities through what Calvin termed God's double grace: justification and sanctification. Calvin was adamant that the peculiar categories of justification and grace should not dissolve as one; yet, the effects of the two forms of grace are inseparable (see Vorster 2019:81). The two forms of grace neither follow a chronological sequence, nor do they stand in a causal relationship with each other. We only distinguish between them, because they have different logical contents. Whereas justification relates to 'being freed' from judgement and being imputed the righteousness of Christ, sanctification relates to a mystic union between God and us that leads to a change in character and the exercise of a Christian lifestyle.

Sanctification points to the regenerative and transformative power of the Spirit who shapes, moulds and forms our lives after the example of Jesus's life. Regeneration therefore follows a particular pattern: Our lives are re-oriented to mirror the image of Christ who constitutes the perfect image of God. We must not equate sanctification with perfection or consummation. Our imaging of God is always an imperfect correspondence affected by finitude and sin (see Tanner 2019:374). Calvin (1864-1900, CO 49.470) rightly contended that the Holy Spirit moves our wills and radiates us with his grace, but the Spirit does not become us, and we do not become God. Sanctification does not entail that we are infused with grace as if it is some kind of ontological substance. Grace rather denotes a new relationship (Van der Kooi \& Van den Brink 2017:662).

The New Testament's alignment of the imago Dei with Jesus Christ is important at this point. Gunton (2018:115) observes that Colossians 1 portrays Jesus as the 'invisible image of God' through whom God reconciles all things to himself. He through whom all things have been created, constitutes the vehicle through which the image is re-established in humanity. Being the image of God means conforming to the example of Christ through the Spirit (Gunton 2018:114). Following Christ involves discipleship, and imaging Christ entails a holy and righteous life inspired by the key virtue that exemplified Jesus' life and that underlies all forms of giving, namely love (see 1 Cor 13; Col 3:10; Eph 4:24).

Dietrich Bonhoeffer rightly insisted that sanctification and discipleship cannot be invisible; it should find expression in visible reality, in history, through the church, which is the sanctified people of God (see Hauerwas 2019:141). The New Testament metaphor of the church as a 'vineyard' of God that must bear good fruit indeed showcases the importance of concrete Christian praxis. The church occupies space and place in time; it mediates Christ's continuing presence in the world not only by proclaiming Christ's reign, but by being a praxis. This understanding of the church stands opposed to any notion of the church as a disembodied gnostic community (see Cavanaugh 2019:44).

As Christ is its Head, justification its source and sanctification its goal, the church presents the main 
location for the formation of a Christian lifestyle. This new reality is symbolised in the sacrament of baptism that denotes our incorporation into the body of Christ. We now belong to Christ, not the world. At the same time, the church community confirms during the ceremony of the sacrament its 'inter-generational' and 'inter-relational' duties towards the baptised (see Van der Kooi \& Van den Brink 2017:605, 609). Embeddedness in the church provides believers with a safe space to mould their identities and to face social challenges that are often beyond individual control. Hauerwas (see Reno 2019:312, 317) holds that the church is an 'identity-forming' power which gives weight and density to Christian identities by telling, retelling, remembering and enacting the story of Christ. In so doing, the church creates life practices that bind people together, a life form that enables them to resist daily afflictions.

The Christian lifestyle and the identity of the church go together. Both are concerned with a way of living and relating that is grounded in Christian beliefs. The New Testament uses various descriptions to articulate the essential features of the church: body of Christ, God's flock, God's family, the elect people of God, a royal priesthood, holy people, people of the way, priesthood of God, God's temple, God's vineyard, letter of Christ, salt of the earth, people of God who proclaims his mighty deeds, et cetera. While these metaphors are used within a wide range of social and literary contexts, the fundamental ingredients remain the same: The church is constituted by God, the church is a holy gathering of believers, the church lives in communio and the church has a missio.

Christ, as the constitutive Head of the church, is the origin and norm of Christian identity formation. Identity formation in the church differs substantially and radically from worldly locations of identity and understandings of power. Tanner (2019) states it most eloquently:

If Jesus is Lord but, unlike human lords, he humbly serves others at dire cost to himself, that says something about the true character of lordship and about why we should be disappointed with every human lord we know. (p. 364)

The universal reign of Christ over all people and nations signifies the church as a catholic community that transcends the boundaries of race, culture and ethnicity. Ethno-cultural, tribal, national and socio-economic identities are not constitutive of the church and cannot be prioritised in the church, but should be assimilated into a larger and more comprehensive identity: being the people of God (see Kalaidzidis 2019:101).

Holiness signifies the distinctive character of the church. The church is a communio sanctorum. One should stress, though, that holiness is not a quality Christians possess, but a status attributed to the church in light of the atoning work of Christ. At the same time, holiness is an aspiration and ideal after which the believer strives. Rowland (2019:35) observes in this regard that the early congregations founded by Paul consisted of small minority groups existing together 'below the radar' in an 'alternative anticipatory space of the common good in the kingdom of God'. It is within these spaces that Christians are exhorted to denounce worldly values, and to embrace distinctive Christian virtues based on the example of the Messiah. The alternative virtues propagated are applicable to all spheres of life: issues such as sex, marriage, family, ownership, labour and politics.

The danger always exists that our sense of holiness and distinctiveness could degenerate into hubris - a false notion of exceptionalism. Various Christian movements throughout history have either fallen into the trap of an otherworldly pietism, or an overly enthusiastic sense of 'great purpose'. Both of these notions are anchored in a misguided exceptionalism. The universal reach of God's reign and love does not allow the church to engage in exceptionalism, because the church is tied into, affected by and concerned with the destiny of created reality. Cavanaugh (2019:434) rightly notes that the kingdom of God is 'not from the world, but is in the world and deeply concerned with it'. Because the whole of reality is the object of God's love, we as the citizens of God's kingdom cannot seclude ourselves from reality or elevate ourselves above reality and, as God alone is sovereign, we have no right to claim greatness.

What is the missio of the church in the world? Reformed theology follows Calvin in understanding the mediating work of Christ from the perspective of Jesus as prophet, priest and king (the munus triplex). The Heidelberg Catechism extends the munus triplex to the life of believers who imitate Christ by being prophets, priests and kings in their own right (Sunday 12, Q/A 32). In light of this, we could state that the church has a prophetic, priestly and royal mandate that qualifies the church as a community of truth, character and hope.

Truth is an essential mode of the kingdom of God. As community of truth, the church proclaims God's reign and witnesses to the Lordship in Christ (martyria) and challenges the broader culture's self-definitions; it exposes demonic power, tyranny, sinful oppressive structures, godless ideologies and social pathologies such as xenophobia. As such, the presence of the church in the world is diagnostic, non-conformist and oppositional in nature. True to its calling, the church neither prescribes to worldly authorities how to exercise power, nor does it subscribe to a particular political ideology or set of policies, but it engages in prophetic truth-telling and social critique when earthly authorities make absolutist claims, become demonic, transgress the limits of justice or challenge the Lordship of Christ. Jenson (2019:454) states it eloquently when he notes that the church has the task to 'relativize worldly kingdoms in order to relate them to God's kingdom'. The church as community of hope draws its identity from the future of God's kingdom in Christ. It lives in an active expectation of the kingdom of God and considers itself as a 'foretaste of God's kingdom' (Zizioulas as cited in Kalaitzidis 2019:101). It enacts God's future as revealed in the incarnation, death and resurrection of Christ by caring for those who suffer and 
are marginalised (diakonia). As such, its presence in the world is promissory, consoling and inspiring. The church, as community of character, follows Christ by worshipping God, living a holy life and engaging in virtuous identity formation (leitourgia). As such, it is an alternative community whose presence in the world is characterised by the cultivation of unique virtues based on the example of Christ. The virtues enacted are relevant to all domains of life, including civil life.

The reformed notion of vocation and calling can be invoked with great effect in reflections on the public role of Christians. Vocation entails that Christians have the duty to obey God in every sphere of social life by respecting divine norms for every mode of existence and by living a virtuous life according to the principles of God's kingdom and the example of Christ. In essence, vocation is about Christians accepting the responsibility to be virtuous exemplars in their communities.

What are the most foundational Christian civic virtues? The best way to reflect on the topic from a biblicaltheological point of view is to take Jesus's public ministry as point of departure. Jesus displayed a friendship that crossed the human boundaries of the time. Whereas modern concepts of friendship tend to limit friendship to the private sphere as if friendliness is a private good, Jesus's friendship was public (see Adams 2019:232; Moltmann 1977:121). As a Jew, he was accessible to Gentiles, he touched unclean people, he related to women and interacted with the socially ostracised (see Van der Kooi \& Van den Brink 2017:473). His friendship coincided with a whole range of benevolent gestures such as empathy, hospitality, treating others with respect, recognition, honesty and self-sacrifice for the sake of the other. Moltmann (1977:116) identifies friendship as a key Christian civic virtue without which there is no hope to overcome power struggles, while Augustine described society as a kind of friendship in which 'human beings strive for a shared good' (Elshtain 2019:45). A striking feature of early Christian communities was the manner in which they extended friendship to those who were not part of the social elite. According to Wannenwetsch (2019:82), it included 'all members of the debased household: women, slaves, children artisans, and so on - a reconciliation of hitherto unreconciled groups and realms of social life'. The end result was a new and unique political identity characterised by full participation in leitourgia of all those

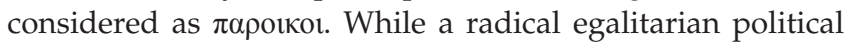
and social order is inconceivable within the broken reality of the 'not yet', the church sets a trajectory, an ideal, that is important: human beings possess equal worth in the eyes of God and therefore deserves to be treated fairly and with equal dignity.

Peace-making is a central theme in Jesus' Sermon of the Mount: 'blessed are the peacemakers because they shall be called children of God' (Mt 5:9). Jesus proclaims love for the enemy (Mt 5:44) and admonishes his disciples to prioritise reconciliation with their enemies even if it comes at the expense of observing religious rituals (Mt 5:24). Forgiveness of sins also played an important role in Jesus' ministry and is continuously, both explicitly and implicitly, present in Jesus' teaching (see Van der Kooi \& Van den Brink 2017:473). His forgiveness consoles, reconciles and sets the lives of sinners on a new path. Christians obviously cannot forgive sins on behalf of God as Jesus did, but they can play a big role in reconciling quarrelling individuals or groups by displaying and advocating a spirit of forgiveness in light of the reconciliatory work of Christ.

Jesus' public ministry, thirdly, displayed extraordinary courage. He had no qualms in confronting the Pharisees and Sadducees. His crucifixion was neither blind fate, nor something merely inflicted on him, but a road he willingly accepted as an act of self-sacrifice (see Van der Kooi \& Van den Brink 2017:481). Bravery is a much-neglected theme in contemporary Christian ethics. Upholding justice in a community not only requires prudence, but often a willingness to resist, to forego securities for the sake of the common good and to stand up and be counted in moments of crisis. Civic virtue requires of Christian citizens to recognise tyranny and systemic injustices, and to challenge rulers who upend the common good for unjust purposes (see Henreckson 2018:48).

Lastly, liberation was a key motive in Jesus' public ministry. According to the Gospel of Luke (4:18-19), Jesus came to 'proclaim release to the captives and recovering of sight for the blind prisoners, to set at liberty those who are oppressed'. The liberation he advocated was not purely spiritual in nature, but manifested concretely in the healing of the sick and reaching out to the poor. Sincere acts of liberation are undergirded and directed by the values of love and justice. The two elements are closely intertwined. According to the gospels, love entails that I treat my neighbour as I want to be treated myself (Mk 12:30, Mt 22:34-40, Lk 10:25-28). Stated differently, love demands fair treatment, while fair treatment is exercised in a spirit of love.

\section{Conclusion}

In this article, I have argued that a tradition can only survive the test of time when it is willing to consistently reform itself. New insights need to be incorporated and aligned to the fundamental intellectual matrix of a tradition, while implausible elements need to be dispensed with. I applied this rationale to the reformed tradition by responding to three contemporary critiques of reformed theology, namely the reformed faith's understanding of God's relation to creation and human uniqueness, reformed understandings of original sin and the transmission of $\sin$, and the inadequacy of an ethics that is purely based on a sola Scriptura premise.

I've addressed these critiques by proposing that reformed theology distinguishes between God's essence and his energies, and incorporates the notion of creation as a gift in its thinking; that it dispenses with realist and federalist 
attempts to explain original sin and the transmission of sin and, instead, replace it with an existential narrative on the nature of sin; and that it works towards an ethics that is both scripturally based and ecclesiastically shaped.

\section{Acknowledgements Competing interests}

The author declares that no competing interest exists.

\section{Author's contributions}

I declare that I am the sole author of this research article.

\section{Ethical consideration}

This article followed all ethical standards for carrying out research without direct contact with human or animal subjects.

\section{Funding information}

This research received no specific grant from any funding agency in the public, commercial or not for profit sectors.

\section{Data availability statement}

Data sharing is not applicable to this article as no new data were created or analysed in this study.

\section{Disclaimer}

The views and opinions expressed in this article are those of the authors and do not necessarily reflect the official policy or position of any affiliated agency of the authors.

\section{References}

Adams, N., 2019, 'Jürgen Moltmann', in W.T. Cavanaugh \& P. Manley-Scott (eds.) The Wiley Blackwell companion to political theology, 2nd edn., pp. 222-236, Wiley Blackwell, Hoboken, NJ.

Barth, K., 1955-1969, Church dogmatics IV/I: The doctrine of reconciliation, transl. G.W Bromiley, T\&T Clark, Edinburgh.

Barth, K., 2018, Church Dogmatics, in M. Cortez \& M.P. Jensen (eds.), Theological anthropology, pp. 33-49, Bloomsbury T\&T Clark, London.

Calvin, J., 1864-1900, loannis Calvini Operae quae supersunt omnia: Ad fidem editionum principium et authenticarum ex parte, in G. Baum \& E. Cunitz \& E, Reuss (eds.), Brunsvigae, Schwetscke.

Cavanaugh, W.T., 2019, 'Church', in W.T. Cavanaugh \& P. Manley-Scott (eds.), The Wiley Blackwell companion to political theology, 2nd edn., pp. 431-444, Wiley Blackwell, Hoboken, NJ.

Conradie, E.M., 2017, An ecological Christian anthropology: At home on earth? Routledge, Abingdon.
Gorringe, T.J., 2019, 'Atonement', in W.T. Cavanaugh \& P. Manley-Scott (eds.), The Wiley Blackwell companion to political theology, 2nd edn, pp. 403-416, Wiley Blackwell, Hoboken, NJ.

Gregory, B., 2012, The unintended reformation: How a religious revolution secularized society, Belknap Press, Cambridge, MA.

Gunton, C., 2018, 'The human creation: Towards a renewal of the doctrine of the imago Dei', in M. Cortez \& M.P. Jensen (eds.), Theological anthropology, pp. 107-117, Bloomsbury T\&T Clark, London.

Hauerwas, S., 2019, 'Dietrich Bonhoeffer', in W.T. Cavanaugh \& P. Manley-Scott (eds.), The Wiley Blackwell companion to political theology, 2nd edn., pp. 137-151, Wiley Blackwell, Hoboken, NJ.

Henreckson, D.P., 2018, 'Resisting the devil's instruments: Early modern resistance theory for late modern times', Journal for the Society of Christian Ethics 38(1), 43-57. https://doi.org/10.1353/sce.2018.0003

Jenson, R.W., 2018, 'Systematic theology', in M. Cortez \& M.P. Jensen (eds.), Theological anthropology, pp. 350-361, Bloomsbury T\&T Clark, London.

Jenson, R.W., 2019, 'Eschatology', in W.T. Cavanaugh \& P. Manley-Scott (eds.), The Wiley Blackwell companion to political theology, 2nd edn., pp. 444-457, Wiley Blackwell, Hoboken, NJ.

Kalaitzidis, P., 2019, 'Eastern orthodox thought', in W.T. Cavanaugh \& P. Manley-Scott (eds.), The Wiley Blackwell companion to political theology, 2nd edn., pp. 97-111, Wiley Blackwell, Hoboken, NJ.

Kierkegaard, S., [1849] 1980, 'The sickness unto death: A Christian psychological exposition for upbuilding and awakening', in Kierkegaard writings, vol. 19, ed. and transl. H.V. Hong \& E.V. Hong, Princeton University Press, Princeton, NJ.

Kierkegaard, S., [1844] 2014, The concept of anxiety: A simple psychologically oriented deliberation in view of the dogmatic problem of hereditary sin, transl. A. Hannay, Liveright, London

Luther, M., 1961, '“Confession concerning Christ's supper” (1528)', in R.H. Fischer (ed.), Luther's works, Vol. 37: Word and Sacrament III, pp. 215-219, Fortress Press, Philadelphia, PA.

McClintock-Fulkerson, M., 2006, 'The imago Dei and a Reformed logic for a feminist/ womanist critique', in A. Plantinga Pauw \& S Jones (eds.), Feminist and womanist essays in reformed theology, pp. 95-106, John Knox Press, Louisville, KY.

Milbank, J., 1995, 'Can a gift be given? Prolegomena to a future Trinitarian metaphysic', Modern Theology 11(1), 119-161. https://doi.org/10.1111/j.1468-0025.1995. Modern Theo

Moltmann, J., 1977, The church in the power of the Spirit, transl. M Kohl, SCM, London.

Niebuhr, R., 1945, The nature and destiny of man: A Christian interpretation, vol. 1, Nisbet, London.

Reno, R.R., 2019, 'Stanley Hauerwas', in W.T. Cavanaugh \& P. Manley-Scott (eds.), The Wiley Blackwell companion to political theology, 2nd edn., pp. 306-320, Wiley Blackwell, Hoboken, NJ.

Ricoeur, P., 1974, 'Original sin. A study in meaning', in D. Ihde (ed.), The conflict of interpretations, pp. 265-284, Continuum, London.

Rowland, C., 2019, 'Scripture: New Testament', in W.T. Cavanaugh \& P. Manley-Scott (eds.), The Wiley Blackwell companion to political theology, 2nd edn., pp. 28-41, Wiley Blackwell, NJ.

Tanner, K., 2018, 'On the difference theological anthropology makes', in M. Cortez \& M.P. Jensen (eds.), Theological anthropology, pp. 50-61, Bloomsbury T\&T Clark, London.

Tanner, K., 2019, 'Trinity', in W.T. Cavanaugh \& P. Manley-Scott (eds.), The Wiley Blackwell companion to political theology, 2nd edn., pp. 363-376, Wiley Blackwell, NJ.

Tillich, P., 1952, The courage to be, Yale University Press, New York, NY.

Van der Kooi, C. \& Van den Brink, G., 2017, Christian dogmatics: An introduction, Eerdmans, Grand Rapids, MI.

Vorster, N., 2019, The brightest mirror of God's works: John Calvin's theological anthropology, Pickwick, Eugene, OR.

Wannenwetsch, B., 2019, 'Liturgy', in W.T. Cavanaugh \& P. Manley-Scott (eds.), The Wiley Blackwell companion to political theology, 2nd edn., pp. 80-95, Wiley Blackwell, Hoboken, NJ.

Westermann, C., 2018, 'The human in the Old Testament', in M. Cortez \& M.P. Jensen (eds.), Theological anthropology, pp. 9-20, Bloomsbury T\&T Clark, London.

Wolff, H.W., 2018, “'Nepesh" in Anthropology of the Old Testament', in M. Cortez \& M.P. Jensen (eds.), Theological anthropology, pp. 150-157, Bloomsbury T\&T Clark, London. 